\title{
Commentary: The grateful state: The 2020 Queensland election
}

\author{
Paul D. Williams \\ paul.williams@griffith.edu.au
}

\begin{abstract}
This article explores the totemic 2020 Queensland state election, at which a twoterm government plagued by a deteriorating economy and widely criticised travel restrictions amid the COVID-19 pandemic was returned with an increased majority. The article posits three arguments: that COVID-19 created a new 'lens' through which electors evaluated public policy and that allowed voters to frame public health and safety over the more usual measures of economic performance; that Queensland voters drew on their traditional political culture especially their predilection for strong leadership and state chauvinism - to evaluate the Palaszczuk Labor government's pandemic management favourably compared with contemporaneous events in Victoria; and that Queensland voters expressed similar confidence in a Labor economic recovery plan that contrasted favourably with the LNP's economic platform. In sum, this article argues that Queenslanders in 2020 cast a 'gratitude vote' for a government they saw as being in control of both public health and economic recovery.
\end{abstract}

\section{Introduction}

The Queensland state election for the 57th parliament, held on 31 October 2020, is of historical significance for several reasons. It was the first election for a Queensland parliament longer than three years' duration since 1893 - courtesy of the referendum of 19 March 2016 to approve fixed four-year parliamentary terms. From this point, Queensland state elections fall on the last Saturday of October every four years. Second, it was the first Australian election at state or national level where both government and opposition leaders were women (Williams 2018e). Third, a record 597 candidates stood across Queensland's 93 electoral districts, including a record 219 women comprising 37 per cent of all candidates (Lynch and Stone 2020). Fourth, Queensland's was the first Australian state - although not territory - election conducted in a COVID-19 environment. Fifth, the Labor government under Premier Annastacia Palaszczuk, seeking a third term, enjoyed a rare swing to it despite high unemployment, increasing state debt and an electorate deeply polarised over rigid border closures designed to control the pandemic. Finally, this election remains notable for Palaszczuk herself. Described as an 
'accidental' premier (McKenna 2021) who, in 2015, ostensibly fell into office after voters rejected the unpopular Liberal-National Party (LNP) Premier Campbell Newman and his government's asset privatisation policy (Williams 2018a), Palaszczuk is now Australia's only female party leader to have won three consecutive elections and, by the dissolution of the 57th parliament, she will be the third longestserving Queensland premier (narrowly overtaking Labor Premier Peter Beattie) and the longest-serving female head of government, at any level, in Australian history. Hardly 'accidental', Palaszczuk has instead played a pivotal role in extending Queensland Labor's second electoral hegemony in which Labor will have governed the state for 30 of the 35 years between 1989 and 2024 (Williams 2001, 2004, 2007, 2010a, 2010b, 2011, 2018a, 2018b, 2018c).

A single research question drives this article: why, despite a deteriorating economy and widely criticised travel restrictions, was the Palaszczuk government returned with an increased majority? I posit three arguments. The first is that COVID-19 created a unique 'lens' through which electors evaluated public policy and election pledges, with voters prioritising public health and safety over the more usual measures of economic performance, such as unemployment and debt. Second, I argue that Queensland's relatively low levels of COVID-19 community transmission contrasted sharply with the experience of Victoria - a state that, in the critical months before the Queensland election, was engulfed by a 'second wave' of COVID-19. Consequently, voters drew on two key pillars of Queensland political culture - strong leadership and state chauvinism (Williams 2009) - and favourably evaluated the performance of the Palaszczuk government. Third, I argue that voter confidence in public health and safety was buttressed by a similar vote of confidence in Labor's post-COVID-19 economic recovery plan that also contrasted favourably with the LNP's economic platform. In sum, I argue that Queenslanders in 2020 cast a 'gratitude vote' for a government they saw as being in control of both public health and economic recovery. The evidence for these conclusions is found in the public opinion data explored below.

\section{Queensland's COVID-19 context}

The Queensland Government moved early to tackle the COVID-19 pandemic. In late January 2020, the state became the first Australian jurisdiction to declare a health emergency, with Health Minister Steven Miles granting special powers to Chief Health Officer Dr Jeanette Young to detain and compulsorily test those suspected of infection (Williams 2020a, p. 681). When the economic impact of the pandemic became clear - Palaszczuk described it as ' 30 cyclones hitting the state at once' - the Queensland Government offered major economic rescue packages, including interest-free loans to local businesses, payments to retrenched workers and rebates on household power bills (Miles 2020).

Coronavirus initially moved quickly throughout South-East Queensland. By mid-March, 100 cases had been diagnosed; by month's end, there were 700 cases and the state's first COVID-19 death had been recorded. In response, parliamentary sittings were postponed until September, and restaurants and cafes became off limits to dine-in patrons. Hotels, clubs, gymnasiums, cinemas and churches also closed. On 26 March, Palaszczuk closed Queensland's borders for the first time in a century, and anyone entering Queensland was required to self-quarantine for two weeks. Schools became 'pupil free' from late March, with students home-schooled 
well into Term 2. By early April, Queenslanders were told to stay home except for four reasons: essential work, to buy food, for medical reasons or to exercise. It was, Palaszczuk said, 'no time for fun' (Ludlow 2020a). On 18 April, Queensland's sixth (and, at the time of writing, last) COVID-19 death occurred just as the state passed 1000 cases. By polling day, Queensland had recorded 1,171 COVID-19 infections (Queensland Government 2021).

The government's economic response, while arguably generous, met with criticism from within its own ranks. The Premier's own Australian Workers' Union was later joined by the United Workers' Union in accusing Palaszczuk of 'selling out' the state's public servants after the government 'froze' a 2.5 per cent wage rise until 1 July 2021 (Elks 2020a). In April, the government announced a public service hiring 'freeze', and concurrently established a 'Treasurer's Advance' (an emergency fund of discretionary spending) of $\$ 3.2$ billion. The government also announced a $\$ 608$ million 'battle plan' for capital works to restore 14,000 jobs, and offered a $\$ 200$ million rescue package for Virgin Airlines just as the company entered voluntary administration with a $\$ 7$ billion debt (Ironside 2020). Tourism Minister Kate Jones conceded that the pandemic had caused up to $\$ 9$ billion damage to Queensland tourism, with the loss of 70,000 jobs (Pierce 2020). In September, new Treasurer Cameron Dick brought down a delayed budget that steered a $\$ 234$ million projected surplus towards an $\$ 8.1$ billion deficit. Interestingly, the details of the budget - captured in the glossy 57-page Queensland Economic Recovery Plan would be carried under the arm of all ministers at every media conference.

Palaszczuk had earlier announced that Queensland's borders would remain closed until New South Wales and Victoria recorded no new cases for one month a decision vehemently opposed by the Premier of New South Wales Gladys Berejiklian, Prime Minister Scott Morrison and much of the conservative news media. Palaszczuk responded in a traditionally populist manner: 'We don't want to put Queenslanders at risk' (Ludlow 2020b). Demands for Palaszczuk to open the borders grew exponentially in June amid claims Queensland was losing \$17 million each day. It was then that LNP leader Deb Frecklington declared that, if she were premier, she would open the borders on 1 July (Johnson and McKay 2020). At precisely that moment, a far more virulent 'second-wave' of community transmission broke across Melbourne.

As above, I argue that sobering news coverage of the Victorian experience (with more than 800 deaths and 18,000 infections by year's end) halted a potential backlash - led by the conservative parties, business groups and a conservative news media - against the Palaszczuk government and its border policies. Instead, the Victorian experience allowed Queensland voters to draw on their predilection for 'strong leadership' and 'state chauvinism' (Williams 2009) to evaluate Palaszczuk as a resolute leader now keeping Queenslanders safe from potentially infectious 'southerners'. As Australians watched Victorians suffer community 'lockdowns', a majority of Queenslanders now appeared grateful for the state's closed borders.

The months between July and October were not trouble-free for the government, however, and the Premier endured a public relations setback - fuelled primarily by three events - over border closures. The first occurred in August when an unborn baby died when a Ballina mother was routed to a Sydney hospital before coming to Queensland. A second occurred when many protested what appeared to be a double standard as interstate footballers and international celebrities gained easy entry to the state. A third galvanised critics when a Canberra nurse was denied permission to 
attend her father's Queensland funeral (Williams 2020b). Palaszczuk was later emotional at media conferences when defending her policy. By year's end, Queensland had 1,250 COVID-19 diagnoses, or 4.4 per cent of the national total.

\section{The 56th parliament}

The previous parliament (2017-20) was dominated by grim economic conditions and ministerial scandals but, paradoxically, a poorly performing LNP opposition saw repeated rumours of a spill against LNP leader Deb Frecklington. Governing with a slim majority, the Palaszczuk government incurred even greater debt Queensland's debt was already the highest in Australia - to facilitate mammoth infrastructure projects aimed at combatting unemployment rates at or the near the worst in the nation. For much of the term, Queensland's joblessness hovered at around 6 per cent, dropping only marginally in 2019 before peaking at 8.8 per cent in July 2020. By polling day, unemployment was 7.7 per cent. Regional youth unemployment was far higher, peaking in October 2020 at 27.9 per cent in Wide Bay (Queensland Government 2020).

Given these challenges, it was inevitable the electorate - and even the Labor party and affiliated trade unions - should polarise over the contentious Indian-owned Adani coal mine in the Galilee Basin. Despite enjoying increased mining royalties, the Queensland Government found it impossible to reconcile urban white-collar voters' demands for action on climate change - and the Greens' preferences that would follow - with regional blue-collar workers' demands for local jobs. With the state government also delaying Stage 3 of the Acland coal mine near Toowoomba, Palaszczuk appeared to grow increasingly cool on the Adani project until federal Labor's trouncing in Queensland at the 2019 federal election. Days after that election, the Palaszczuk government approved the mine (Williams 2019, p. 670). Anti-coal protests soon blocked the streets of Brisbane's CBD (Williams 2020c, p. 341).

Natural disasters also plagued the state. In 2018, Cyclone Owen caused flooding in North Queensland despite 67 per cent of the state remaining drought-declared. Rare bushfires in North and Central Queensland followed, with air quality in the south-east severely affected. That year also saw the government pass its iconic Vegetation Management and Other Legislation Amendment Bill, which protected more land from clearing (Williams 2018d, p. 679).

Ethics featured prominently during the term. In 2018, the then Main Roads Minister Mark Bailey was referred to, and eventually cleared but reproached by, the Crime and Corruption Commission (CCC) over his use of a private email account to conduct ministerial business. That same year, former Pauline Hanson's One Nation (PHON) Queensland Senator Fraser Anning, later adopted by Katter's Australian Party (KAP), called for a 'final solution' to Australia's immigration 'problem'. Anning attracted near-universal condemnation, including from Premier Palaszczuk, whose Polish grandparents had fled Nazi persecution. When the KAP refused to condemn Anning - despite later expelling him - Palaszczuk withdrew some of KAP's parliamentary resources. KAP referred Palaszczuk to the CCC; it handed the matter back to the Legislative Assembly's Ethics Committee, which in 2019 found Palaszczuk guilty of contempt of parliament (Vogler 2019).

Far more damaging, however, were two events surrounding Deputy Premier Jackie Trad. In July 2019, the Courier-Mail reported that Trad's husband had 
purchased an investment property in Woolloongabba along the route of the proposed Cross-River Rail (CCR) project (Wardill 2019). Given that Trad was also Treasurer and Minister Responsible for CCR, the potential conflict of interest was clear. Trad referred herself to the CCC, which found she had not committed a crime but had breached Cabinet rules. New legislation was subsequently enacted to criminalise deliberate failures to declare ministerial conflicts of interest. Trad was again referred to the CCC for allegedly interfering in the selection of a school principal in her South Brisbane electorate. In mid-2020, the CCC cleared Trad, but again not without rebuke. Critically, support for Trad from within her own faction diminished and she resigned from Cabinet. But Trad's future had already been sealed after an LNP State Executive decision to preference Trad below the Greens in South Brisbane (Williams 2019, p. 673).

One of Trad's sternest critics was fellow left MP Jo-Ann Miller. But when left support for Miller also diminished, the independently minded MP resigned her Bundamba electorate. Labor retained the seat - despite an 11.8 per cent two partypreferred (2PP) swing against it - at the by-election on 28 March 2020 (ECQ 2020a). Frontbench changes thereafter saw the left's power diminished, with the AWU-aligned Cameron Dick assuming Treasury and the left-aligned Steven Miles appointed Deputy Premier.

The LNP suffered its own dilemmas after attempts at branch-stacking by ultraconservative 'religious right' elements, and following Whitsunday MP Jason Costigan's expulsion after being accused of 'intimidating and frightening' an 18-year-old woman (Caldwell 2019). In late 2019, Costigan registered his own North Queensland First Party and fielded five candidates. PHON also struggled with integrity issues in 2019 after covertly filmed footage showed the then state leader Steve Dickson and Hanson adviser James Ashby in the United States discussing potential donations from the National Rifle Association. Later, more footage was released of Dickson making racially insensitive and sexist remarks inside an American strip club (Williams 2019, p. 674).

Abortion was removed from the state's Criminal Code in 2018 after a conscience vote (allowed by both major parties) easily passed the Termination of Pregnancy Bill. But LNP President Gary Spence warned MPs not to support the Bill. Three LNP MPs crossed the floor, with one - Jann Stuckey (Currumbin) - later alleging victimisation. Stuckey resigned in early 2020 and Labor almost won the seat on 28 March 2020 after enjoying the first by-election swing (2.1 per cent $2 \mathrm{PP})$ to a government since 2000 (ECQ 2020b). Spence also resigned when new laws prohibiting donations from property developers came into effect. In 2020, the Electoral Act was again amended to include election campaign 'spending caps'. From 2020, party-endorsed candidates may spend a maximum of $\$ 57,000$, with parties allowed to spend an additional $\$ 92,000$ per seat. Independents are allowed to spend a maximum of $\$ 87,000$, while 'third parties' such as business groups and trade unions would also be capped at $\$ 87,000$ per seat, or $\$ 1$ million overall. From 2022, a \$10,000 per term donation cap will also apply (Caldwell 2020a).

\section{Pre-campaign}

Even before Governor Paul de Jersey issued the election writs on 6 October, a significant number of policies had been released to frame a campaign around not only the COVID-19 pandemic and border controls, but major infrastructure 
(especially roads and water) and law and order. Labor, for example, pledged a $\$ 50$ billion 'infrastructure guarantee'; the building of a second M1 Gold Coast freeway; 2025 new police officers and extra resources for youth crime hot-spots around Townsville; the construction of nine new schools and the hiring of 6,000 new teachers; an expansion of regional and outer suburban hospitals; mining royalty 'freezes' for LNG and coal companies; and \$145 million for renewable energy (Courier-Mail 2020a).

In turn, the LNP promised a $\$ 33$ billion Bruce Highway upgrade along the 1,600 kilometres between Gympie and Cairns - 80 per cent of which relied upon federal funding not yet secured from Prime Minister Scott Morrison (a point that appeared to undermine voter confidence in the LNP's economic credentials); a revival of the 1930s Bradfield irrigation scheme to divert northern rivers westward; the hiring of 1,000 new police officers and a 'crackdown' on youth crime; a 'decluttering' of the school curriculum; Galilee Basin mining projects totalling $\$ 50$ billion; the establishment of an Economic Recovery Agency; and a pledge to 'stabilise' debt (CourierMail 2020b).

\section{The campaign proper}

\section{Week 1: 6-10 October}

The first week saw each major party leader don a fluoro vest and hard hat to campaign on infrastructure. Labor performed well as Palaszczuk offered twin pledges: 'keeping Queensland safe and keeping people in work' (Palaszczuk 2020). The LNP was less impressive, especially after the LNP declared that all Labor candidates would be preferenced below the Greens - a decision that, anecdotally, sat uncomfortably with rank-and-file LNP members. PHON and KAP announced their own preference exchange. While the LNP focused on youth lawlessness, especially in marginal Labor seats around Cairns and Townsville, Labor embarked upon its own fear campaign via allegations that an LNP government would revisit the frontline public service spending cuts of the Newman government, in which Frecklington was an assistant minister. The LNP responded with a $\$ 300$ car registration rebate costed at $\$ 1.15$ billion. Critically, Prime Minister Scott Morrison - the only federal presence - then joined Frecklington on the campaign, with Frecklington suggesting that Dr Jeanette Young should 'have a hard look' at border exemptions (Peel 2020a). Electoral rolls and nominations closed on 10 October and 11 October respectively.

\section{Week 2: 11-17 October}

The campaign's second week began so horrendously for Frecklington that many rated the LNP campaign terminal. On 13 October, the $A B C$ News website posted a story suggesting Frecklington had attended fundraising dinners with LNP supporters alleged to have been property developers. The $\mathrm{ABC}$ also said around $\$ 150,000$ was subsequently donated to the LNP, and that the LNP itself had referred Frecklington to the Electoral Commission of Queensland (ECQ) - a claim the LNP vehemently denied. Frecklington conceded that she had attended the functions but stood by her integrity. Attendees said the dinners were not fundraisers but merely 'gathering[s] of like-minded people' (Robertson 2020). Remarkably, the story soon disappeared from the campaign narrative. Attention now turned to 
Labor after Palaszczuk left open the opportunity for Trad to re-join Cabinet, then ruled out that prospect following intense criticism. United Workers' Union Queensland Secretary Gary Bullock then criticised Palaszczuk, insisting that Labor boasted democratic practices (Courier-Mail 2020c). That same week, former Labor Brisbane Lord Mayor Jim Soorley, now chair of the state-owned energy company CS Energy, was referred to the CCC for allegedly working as a lobbyist, a role prohibited for serving government board members (Ludlow and Walsh 2020). These events led the CCC to issue a written warning to every candidate to remain aware of conflicts of interest. As Morrison left Queensland, Frecklington announced an ambitious plan - not seen since Peter Beattie's own 1998 pledge - to lower unemployment to 5 per cent (or 73,000 new jobs) within the term, a target Palaszczuk described as 'irresponsible' (Marszalek, Wray and McKay 2020). With the LNP pledging to double the value of Queensland's agricultural output by 2035, the opposition leader also promised to 'overhaul' government procurement processes. Frecklington closed the week by declaring her party would preference the anti-vaccination Informed Medical Options Party (IMOP) below Labor in every seat.

\section{Week 3: 18-24 October}

The LNP opposition enjoyed an improved performance during the third week, and some now predicted a hung parliament. Each major party held its campaign launch a week early - on Sunday, 18 October - to capitalise on the commencement of prepoll voting on 19 October. Palaszczuk framed her pitch around keeping Queenslanders safe during the pandemic, while Frecklington painted a picture of a grim economic future should Labor be re-elected. Interestingly, Palaszczuk surprised many when she pledged to legislate for voluntary assisted dying (euthanasia) early in 2021 - a policy that raised the hackles of church leaders. The following day, Labor launched its 'Cuts Express' bus that, in linking Frecklington to Newman, would visit 80 electorates to warn of LNP spending cuts. But some of that message was lost when several regional Labor MPs and candidates - supported by the Queensland Council of Unions - urged voters to ignore Labor's official position of numbering PHON candidates last (Elks 2020b). Deputy Premier Miles then met criticism when he described some micro-party candidates as 'freaks and weirdos' (Marszalek, Cameron and McKay 2020). It was also noted that Frecklington's photograph did not appear on LNP How-to-Vote cards. The week also saw Clive Palmer's United Australia Party echo the 2019 federal election, alleging via a mass advertising campaign a secret Labor 'death tax'. Federal MP Bob Katter, campaigning for his son and KAP state leader Robbie, was then accused of bullying LNP volunteers at pre-poll centres. Law and order returned to the campaign as Frecklington pledged a six month trial of night-time curfews for youths in Cairns and Townsville, with parents fined $\$ 250$ per breach - a policy Labor described as racist. The LNP then pledged to immediately open Stage 3 of the long-stalled Acland coal mine, but any kudos appeared lost in the criticism of an LNP opposition refusing to release its costings until the campaign's last days. Indeed, even the Courier-Mail newspaper editorialised that a failure to deliver timely costings 'will hurt Deb if not put to bed' (Courier-Mail 2020d). The week closed with a war of words between the Queensland and NSW premiers over border closures. When Berejiklian urged Palaszczuk to open the border, the Queensland Premier replied, 'I'm not going to be lectured by the Premier of NSW' (Elks 2020c). But Palaszczuk herself was criticised when she 
refused to release the findings of a private Ipsos opinion poll, costing over $\$ 500,000$, to assess Queenslanders' views on the government's pandemic management. It was at this point that Frecklington herself appeared unclear about when an LNP government would open the border, insisting 'the borders should not be closed for a day longer than they have to be' (Morris-Grant 2020). This ambiguity contrasted sharply with the LNP leader's earlier demands for a July opening.

\section{Week 4: 25-31 October}

The week began with both major party leaders visiting the three marginal Labor seats around Townsville for a fourth time. With North Queensland appearing especially conscious of its regional power, the KAP pledged to hold a referendum on northern secession, with those in the south-east unable to participate. One opinion poll pegged northern support for separation at 57 per cent (McCormack 2020). On 26 October, Labor released its policy costings at $\$ 4.3$ billion, confirming that the government would borrow $\$ 4$ billion - raising state debt to $\$ 102$ billion - with four successive budget deficits. As a sweetener, the Treasurer promised an extra 5,800 nurses, 1,500 additional doctors and another 1,700 allied health workers to be paid for via a 2 per cent annual 'productivity dividend' (about $\$ 270$ million annually) saved from Queensland Health's budget. Treasurer Cameron Dick denied that the dividends were 'cuts' and promised to keep public service increases below a state population growth now the lowest since World War I (Elks 2020d). Mid-week saw a Sky News/Courier-Mail leaders' debate attended by 100 voters. Here, a more aggressive Palaszczuk again argued her border policy had kept Queenslanders safe while advocating a vote for the LNP, even the Courier-Mail newspaper editorialised that Palaszczuk's pandemic response was 'world-leading' (Courier-Mail 2020e) while simultaneously asking how the LNP would fund its policies. Frecklington focused on Queensland's economic woes, but 53 per cent of the audience still rated Palaszczuk the debate's victor, with 30 per cent opting for Frecklington and 17 per cent undecided (Peel and Elks 2020). Thursday, 29 October saw the LNP release its costings with a promise of no forced public service redundancies, no new taxes and no asset sales. With the LNP's infrastructure budget now costed at $\$ 5.05$ billion, the LNP also committed itself to a budget surplus within four years by borrowing $\$ 1.3$ billion, adopting a 2 per cent public service efficiency dividend and extending Labor's public service hiring freeze (Peel 2020b). The LNP also promised 3,350 more teachers, 854 more police officers, 2,530 new nurses, 750 additional doctors and 124 more child safety officers. With former Labor Premier Peter Beattie also urging Palaszczuk to open the borders, the campaign ended with Palaszczuk's long-awaited announcement that Queensland would open to New South Wales, but not to Greater Sydney, on 1 November; the decision infuriated business. The closing days also revealed the parties' donations: in the last month of the campaign, the LNP received $\$ 1.3$ million (double Labor's $\$ 646,000$ ), with the KAP receiving $\$ 84,000$, the Greens $\$ 52,000$ and PHON just $\$ 7,900$ (Scott 2020). The betting markets closed with a Labor victory earning $\$ 1.20$ and an LNP win $\$ 4$ (Courier-Mail 2020f). Six MPs retired at the election: Kate Jones (Labor, Cooper), Anthony Lynham (Labor, Stafford), Coralee O'Rourke (Labor, Mundingburra), Mark McArdle (LNP, Caloundra), Ted Sorensen (LNP, Hervey Bay) and first-term MP Simone Wilson (LNP, Pumicestone). 


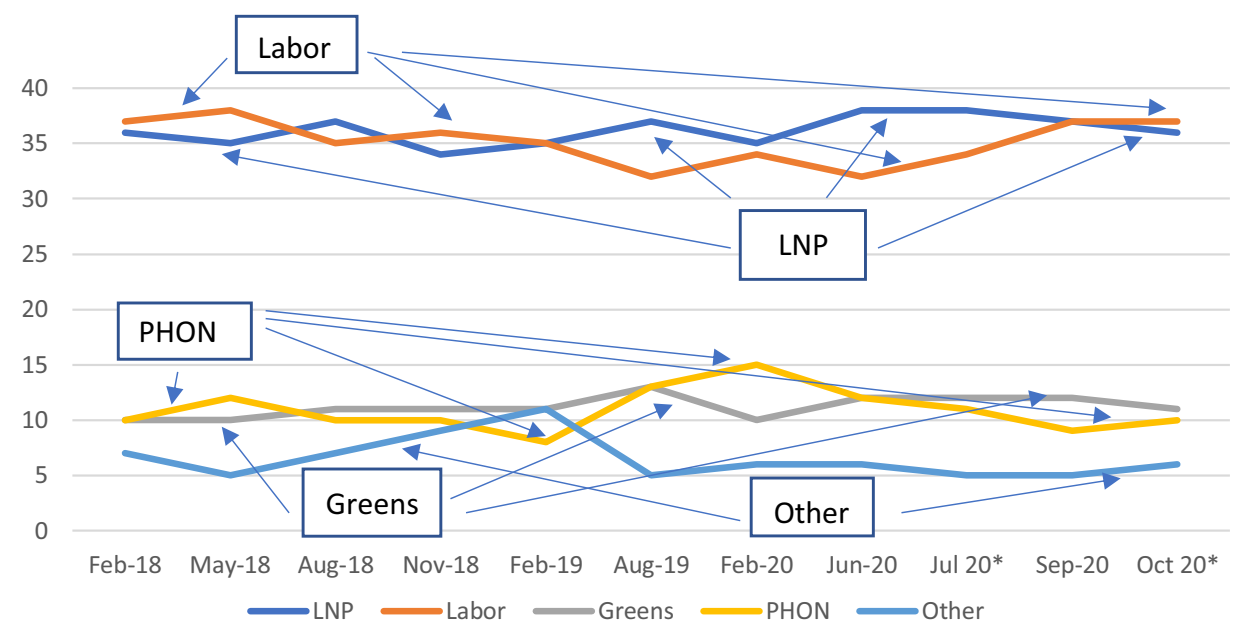

Figure 1

Queensland primary vote, 2018-20 (\%).

Source: YouGov and Newspoll, 2018-20.

Note: All polls are YouGov except those denoted *. LNP = Liberal-National Party; PHON = Pauline Hanson's One Nation; Other includes Katter's Australian Party, Civil Liberties \& Motorists Party; Shooters, Farmers and Fishers Party, North Queensland First, Animal Justice Party, Clive Palmer's United Australia Party, Informed Medical Options Party; Legalise Cannabis Qld; Independents.

\section{Public opinion}

Figure 1 reveals that the major parties' primary vote remained close over the period despite the lead changing hands on four occasions. The primary vote was also steady, with each major party ending the parliament almost exactly where it began. While the Greens' vote also stabilised, PHON declined during 2020 - due in part to Hanson's low profile before and during the campaign - with the micro party and independent vote also collapsing in late 2019.

Figure 2 reveals wider discrepancies between the major parties' after-preference support. With the LNP overtaking Labor only briefly in mid-2019, Labor finished the campaign on 51.5 per cent 2 PP to the LNP's 48.5 per cent - again, close to where the parties began the term.

Figure 3 indicates that voter satisfaction with Palaszczuk plummeted as integrity issues engulfed Deputy Premier Jackie Trad in mid-2019, but rebounded strongly as COVID-19 gripped Queensland in early 2020. Indeed, by polling day Palaszczuk enjoyed a net satisfaction rating of +30 points. Conversely, voters' satisfaction with opposition leader Frecklington declined in the second half of 2019 and, despite recovering in 2020, Frecklington spent the last fourteen months of her leadership in negative territory to end the campaign with a net satisfaction rating of -7 points.

Figure 4 offers further evidence of how the government's management of the COVID-19 pandemic enhanced Palaszczuk's public opinion standing - with a marked increase in her lead from mid-2020 - and allowed Palaszczuk to be contrasted favourably with an opposition leader who appeared ambiguous on 


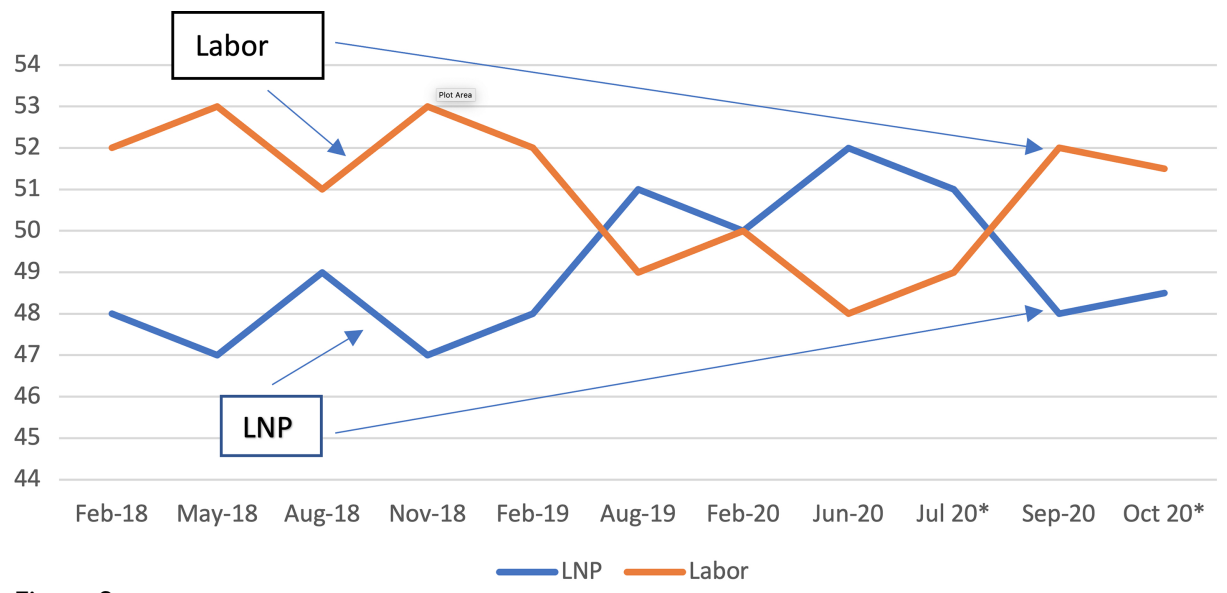

Figure 2

Queensland two party-preferred vote, 2018-20 (\%).

Source: YouGov and Newspoll, 2018-20.

Note: All polls are YouGov except those denoted *.

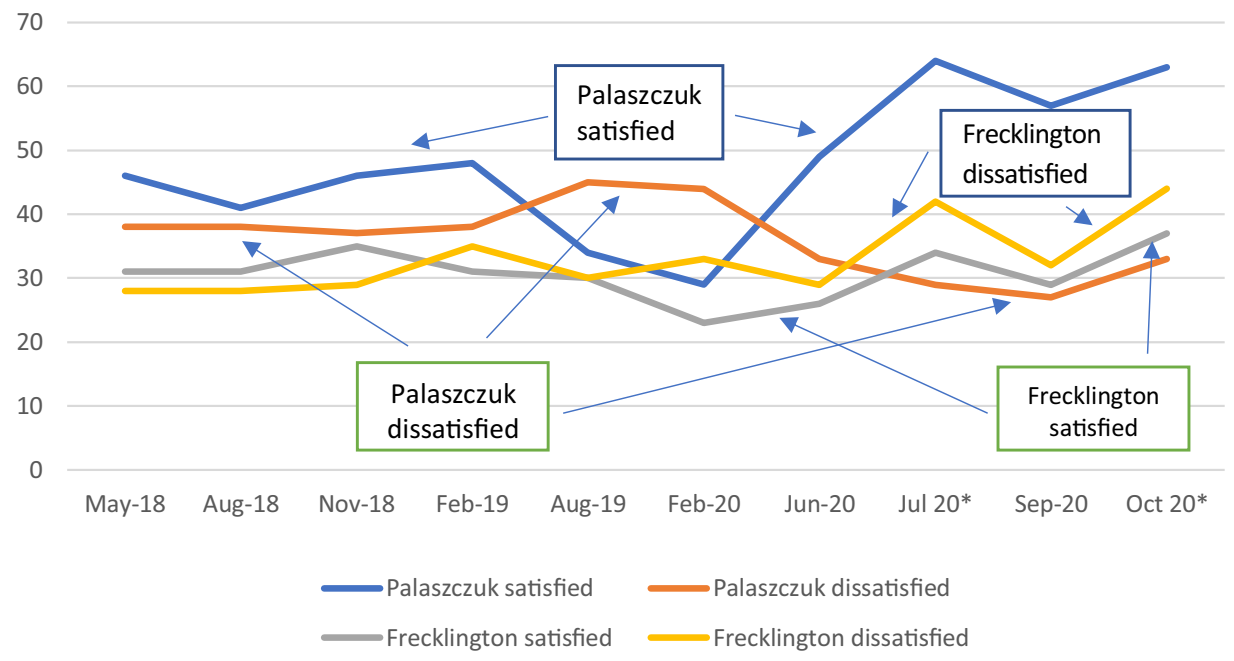

Figure 3

Major party leaders' satisfaction/dissatisfaction, 2018-20 (\%).

Source: YouGov and Newspoll, 2018-20.

Note: All polls are YouGov except those denoted *.

her border policy. Critically, at no point did Frecklington overtake Palaszczuk as preferred Premier.

\section{COVID-19 and economy polling}

A July Newspoll found that 81 per cent of Queenslanders approved of Palaszczuk's handling of the pandemic, with 69 per cent still approving in late September. Only 


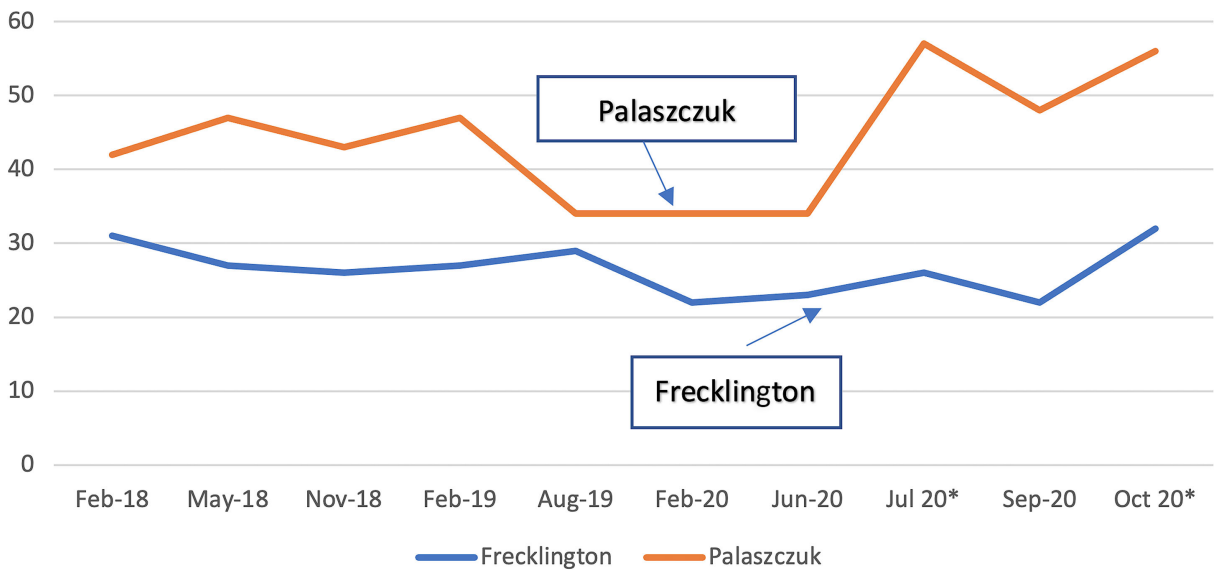

Figure 4

Preferred Premier, 2018-20 (\%).

Source: YouGov and Newspoll, 2018-20.

Note: All polls are YouGov except those denoted *.

one in five Queenslanders was dissatisfied with Palaszczuk's pandemic management. Moreover, a majority of Queenslanders (53 per cent) believed Palaszczuk's border restrictions were 'about right', with 37 per cent saying they were 'too strict' and 7 per cent 'too lenient' (Ransley 2020). Anecdotal evidence was also reported that Palaszczuk enjoyed the support of voters aged over 65 years - a core PHON constituency - with older women especially grateful for Palaszczuk's pandemic management (Fraser 2020). Almost as critical is an Ipsos poll that, late in the campaign, found 50 per cent of Queensland voters rating Palaszczuk a better economic manager than Frecklington (Ludlow 2020c). Moreover, a mid-campaign Newspoll found 43 per cent of voters believed Palaszczuk's Labor government would be 'more effective' in job creation, with just 29 per cent of voters expressing similar confidence in Frecklington (Fraser and Walker 2020).

\section{Results}

Table 1 reveals that Labor enjoyed a 4.14 per cent primary swing, or 1.9 per cent 2PP, and a net increase of four seats for a Legislative Assembly share of 52.

Labor gained five seats from the LNP (Bundaberg, Caloundra, Hervey Bay, Nicklin and Pumicestone) to make inroads into the LNP-dominated Sunshine Coast. Labor lost one seat (South Brisbane) to the Greens - continuing the 'greening' of Queensland (Williams 2006) - while the LNP made one gain, retaking Whitsunday from North Queensland First for a Legislative Assembly share of 34. Paradoxically, while the LNP lost representation, it nonetheless increased its primary vote by 2.2 percentage points. The Greens' extra seat arrived despite a slight diminution in its overall vote, while PHON (1) and KAP (3) maintained their previous representation, despite PHON's vote almost halving (a result made grimmer by the fact PHON stood 29 more candidates than in 2017). The Independent MP for Noosa, Sandy Bolton, was also returned. Despite a record 


\begin{tabular}{|c|c|c|c|c|c|c|c|c|}
\hline Party & $\begin{array}{c}\text { Primary } \\
\text { vote } 2020\end{array}$ & $\begin{array}{l}\text { Primary swing over } \\
\qquad 2017(+\mid-)\end{array}$ & $\begin{array}{l}\text { 2PP vote } \\
2020\end{array}$ & $\begin{array}{l}\text { 2PP swing over } \\
2017(+/-)\end{array}$ & $\begin{array}{l}\text { Nom. } \\
2020\end{array}$ & $\begin{array}{l}\text { Nom. change over } \\
2017(+/-)\end{array}$ & $\begin{array}{c}\text { Seats } \\
\text { won } 2020\end{array}$ & $\begin{array}{l}\text { Seats change over } \\
2017(+/-)\end{array}$ \\
\hline Labor & 39.57 & +4.14 & 53.2 & +1.9 & 93 & 0 & 52 & +4 \\
\hline LNP & 35.89 & +2.20 & 46.8 & -1.9 & 93 & 0 & 34 & -5 \\
\hline Greens & 9.47 & -0.53 & - & - & 93 & 0 & 2 & +1 \\
\hline PHON & 7.12 & -6.60 & - & - & 90 & +29 & 1 & 0 \\
\hline KAP & 2.52 & +0.20 & - & - & 13 & +3 & 3 & 0 \\
\hline UAP & 0.62 & +0.62 & - & - & 55 & +55 & 0 & - \\
\hline LCQP & 0.91 & +0.91 & - & - & 23 & +23 & 0 & - \\
\hline IMOP & 0.61 & +0.61 & - & - & 31 & +31 & 0 & - \\
\hline AJ & 0.34 & +0.34 & - & - & 13 & +13 & 0 & - \\
\hline NQF & 0.20 & +0.20 & - & - & 5 & +5 & 0 & - \\
\hline CLMP & 0.18 & -0.08 & - & - & 16 & +8 & 0 & - \\
\hline SFF & 0.10 & +0.10 & - & - & 3 & +3 & 0 & - \\
\hline Ind. & 2.48 & -2.10 & - & - & 597 & +144 & 1 & 0 \\
\hline
\end{tabular}

Source: ECQ (2021).

Note: Nom. = Nominations LNP = Liberal-National Party; PHON = Pauline Hanson's One Nation; KAP = Katter's Australian Party; UAP = Clive Palmer's United Australia Party; LCQP = Legalise Cannabis Queensland; IMOP = Informed Medical Options Party; AJ = Animal Justice Party; NQF = North Queensland First; CLMP = Civil Liberties \& Motorists Party; SFF = Shooters, Farmers and Fishers Party; Ind = Independents 
advertising blitz, UAP recorded just 0.62 per cent, lower than the Legalise Cannabis party. The informal vote was 3.3 per cent (down 0.94 points from 2017) and participation was 87.92 (up 0.39 points). This election also saw a record number of pre-poll votes cast (1.29 million, or a 74 per cent increase over 2017), and 750,000 postal votes - more than double the 2017 total (Caldwell 2020b). With 930,000 Queenslanders (or just 31 per cent) attending a polling booth on 31 October, we can assume Queensland now enjoys an election 'period' rather than an election 'day' (ECQ 2021).

\section{Conclusion}

The evidence found in the public opinion poll data explored above answers the core question of why, despite a deteriorating economy and widely criticised travel restrictions, the Palaszczuk government was returned with an increased majority. Indeed, the data confirm this article's three arguments: that Queenslanders prioritised public health and safety; that voters contrasted Queensland's relatively low numbers of COVID-19 cases with Victoria's 'second wave'; and that voters also contrasted Labor's post-COVID-19 economic recovery plan favourably with that of the LNP. In short, Queenslanders in 2020 appeared to cast a 'gratitude vote' for a government they saw as being in control of both public health and economic recovery. Given that three of the seats Labor won from the LNP - Pumicestone (29.49 per cent) Caloundra (24.46 per cent) and Bundaberg (22.60 per cent) - were home to a significantly higher proportion of voters aged over 65 years than the state average (15.8 per cent), anecdotal evidence of a Labor surge from 'Palaszczuk's pensioners' (Fraser 2020) appears to be at least partially supported. Finally, we can conclude that this 'crisis' election saw voters abandon the minor and micro-parties (KAP was the only incumbent minor to increase its primary vote) and return to the major parties of the political centre. We can also conclude that a COVID-19 political context offers governments something of an electoral advantage given elections in 2020 in Queensland, the Northern Territory, the Australian Capital Territory and New Zealand all saw incumbents easily returned. For Queensland, Labor's second electoral hegemony continues unabated.

\section{References}

Caldwell, F. 2019, “Intimidating and frightening”: LNP details complaints against Costigan', Brisbane Times, 13 February.

Caldwell, F. 2020a, 'Campbell Newman's ex-sparring partner helped paint Labor to victory', Brisbane Times, 28 November.

Caldwell, F. 2020b, 'Future elections could go fully postal amid fallout from COVID19', Brisbane Times, 18 November.

Courier-Mail 2020a, 'The big pitch: What the parties are promising', 6 October, p. 70.

Courier-Mail 2020b, 'Best choice to ensure state moves forward', 25 October, p. 70.

Courier-Mail 2020c, 'Premier should be the boss of Cabinet', 13 October, p. 36.

Courier-Mail 2020d, 'Costings blow will hurt Deb if not put to bed', 29 October, p. 44.

Courier-Mail 2020e, 'Queensland needs a change in direction', 30 October, p. 62.

Courier-Mail 2020f, 'Late betting money backs Labor minority', 1 November, p. 15. 
Electoral Commission of Queensland (ECQ) 2020a, 'Bundamba state by-election'. Available from: https://results1.elections.qld.gov.au/bundamba2020/bundamba [1 December 2020].

Electoral Commission of Queensland (ECQ) 2020b, 'Currumbin state by-election'. Available from: https://results1.elections.qld.gov.au/currumbin2020/currumbin [1 December 2020].

Electoral Commission of Queensland (ECQ) 2021, 2020 state general election. Available from: https://results.elections.qld.gov.au/state2020 [1 December 2020].

Elks, S. 2020a, 'Unions at war over freeze in wages', Australian, 9 June, p. 4.

Elks, S. 2020b, 'Premier bowled as candidate goes rogue', Australian, 20 October, p. 2. Elks, S. 2020c, 'Premiers throwing stones on borders', Courier-Mail, 23 October, p. 16. Elks, S. 2020d, 'Extra \$4bn debt to pay for Labor promises', Australian, 27 October, p. 6.

Fraser, A. 2020, “"Pensioners” swayed by Premier's grit', Australian, 26 October, p. 7. Fraser, A. and Walker, J. 2020, 'Election polls back Labor's jobs push', Australian, 19 October, p. 2.

Ironside, R. 2020, 'Virgin drowning in debt', Courier-Mail, 25 April, p. 3.

Johnson, H. and McKay, J. 2020, 'Jobs go but blockade stays', Courier-Mail, 20 June, p. 9.

Ludlow, M. 2020a, 'When it's okay to take your tinny out fishing', Australian Financial Review, 2 April, p. 9.

Ludlow, M. 2020b, 'Neighbours who “just don't like each other"', Australian Financial Review, 28 May, p. 10.

Ludlow, M. 2020c, 'Poll backs Palaszczuk to manage economy', Australian Financial Review, 28 October, p. 9.

Ludlow, M. and Walsh, L. 2020, 'Palaszczuk ministers stand by Soorley', Australian Financial Review, 17 October, p. 8.

Lynch, L. and Stone, L. 2020, 'Women lead Queensland election campaign, but remain firmly in the minority', Brisbane Times, 16 October, p. 1.

McCormack, M. 2020, 'Katter bid to split north', Courier-Mail, 26 October, p. 13.

McKenna, M. 2021, 'Premier's resolute stand turned tide', Australian, 8 January, 2021, p. 6.

Marszalek, J., Cameron, D. and McKay, J. 2020, “"Freaks and weirdos” first', CourierMail, 21 October, p. 7.

Marszalek, J., Wray, M. and McKay, J. 2020, 'Record we would rather avoid', CourierMail, 16 October, p. 4.

Miles, J. 2020, 'A constant state of readiness', Courier-Mail, 18 April, p. 4.

Morris-Grant, B. 2020, 'LNP's mixed messages over border reopening', Courier-Mail, 23 October, p. 15.

Palaszczuk, A. 2020, 'State can't risk going backwards', Courier-Mail, 6 October, p. 70. Peel, C. 2020a, 'Heat on border permit process', Courier-Mail, 12 October, p. 8.

Peel, C. 2020b, 'No asset sales, no new taxes in LNP plan', Australian, 30 October, p. 6.

Peel, C. and Elks, S. 2020, 'Premier falls back on borders', Australian, 29 October, p. 7.

Pierce, J. 2020, '56 billion reasons to lure travellers', Courier-Mail, 26 April, p. 13. 
Queensland Government 2020, 'Labour and employment'. Available from: https:// www.qgso.qld.gov.au/statistics/theme/economy/labour-employment/state [1 December 2020].

Queensland Government 2021, 'Queensland COVID-19 statistics'. Available from: https:/www.qld.gov.au/health/conditions/health-alerts/coronavirus-covid-19/currentstatus/statistics\#cumulative [1 December 2020].

Ransley, J. 2020, 'Two-thirds of Queenslanders back Annastacia Palaszczuk as state election looms', News.com, 22 September. Available from: https:// www.news.com.au/national/queensland/politics/twothirds-of-queenslanders-backannastacia-palaszczuk-as-state-election-looms/news-story/ 46b9fb24eb42bf41a50719db7f132094 [1 December 2020].

Robertson, J. 2020, 'LNP opposition leader Deb Frecklington campaign in crisis after being referred by own party to election watchdog', $A B C$ News, 13 October. Available from: https:/www.abc.net.au/news/2020-10-13/lnp-crisis-as-debfrecklington-referred-to-election-watchdog/12748400 [1 December 2020].

Scott, M. 2020, 'LNP trounces Labor in donor stakes', Australian, 28 October, p. 7. Vogler, S. 2019, 'Ethics Committee hits out at Katter comments', Courier-Mail, 5 November, p. 5.

Wardill, S. 2019, 'Jack's shack could make her a stack', Courier-Mail, 18 July, p. 2.

Williams, P.D. 2001, 'The Queensland election of 17 February 2001: Reforging the electoral landscape?' Australian Journal of Political Science, vol. 36, no. 2, pp. 363-71.

Williams, P. D. 2004, 'The Queensland election of 7 February 2004: The coming of the second Labor hegemony?', Australian Journal of Political Science, vol. 39, no. 3, pp. 635-44.

Williams, P. D. 2006, 'The greening of the Queensland electorate?' Australian Journal of Political Science, vol. 41, no. 3, pp. 325-37.

Williams, P.D. 2007, 'Defying the Odds: Peter Beattie and the 2006 Queensland Election'. Australasian Parliamentary Review, 22 (2): 212-20.

Williams, P.D. 2009, 'Leaders and political culture: The development of the Queensland Premiership, 1859-2009', Queensland Review, vol. 16, no. 1, pp. 15-34.

Williams, P.D. 2010a, 'The Queensland election of 21 March 2009: Labor's swim against the tide', Australian Journal of Political Science, vol. 45, no. 2, pp. 277-83.

Williams, P.D. 2010b, 'Time of transition: The Queensland parliament and electoral volatility, 2008-09', Australasian Parliamentary Review, vol. 25, no. 1, pp. 224-39.

Williams, P.D. 2011, 'How did they do it? Explaining Queensland Labor's second electoral hegemony', Queensland Review, vol. 18, no. 2, pp. 112-33.

Williams, P.D. 2018a, 'Leadership or policy: Explaining the Queensland election of 31 January, 2015', Australian Journal of Politics and History, vol. 64, no. 2, pp. 1-17.

Williams, P.D. 2018b, 'Back from the brink: Labor's re-election at the 2017 Queensland state election', Queensland Review, vol. 25, no. 1, pp. 6-26.

Williams, P.D. 2018c, 'One, two or many Queenslands? Disaggregating the regional vote at the 2017 Queensland state election', Australian Parliamentary Review, vol. 33, no. 2, pp. 57-79.

Williams, P.D. 2018d, 'Political chronicle: Queensland, January to June, 2018', Australian Journal of Politics and History, vol. 64, no. 4, pp. 673-80. 
Williams, P.D. 2018e, 'Political chronicle: Queensland, July-December, 2017', Australian Journal of Politics and History, vol. 64, no. 2, pp. 329-38.

Williams, P.D. 2019, 'Political chronicle: Queensland, January to June, 2019', Australian Journal of Politics and History, vol. 65, no. 4, pp. 669-76.

Williams, P.D. 2020a, 'Political chronicle: Queensland, January to June, 2020', Australian Journal of Politics and History, vol. 66, no. 4, pp. 681-87.

Williams, P.D. 2020b, 'Premier falls behind in election nail-biter', Courier-Mail, 16 September, p. 61.

Williams, P.D. 2020c, 'Political chronicle: Queensland, July-December, 2019', Australian Journal of Politics and History, vol. 66, no. 2, pp. 339-46.

Paul Williams is a Senior Lecturer in politics, journalism and public relations in Griffith University's School of Humanities, Languages and Social Sciences. He has published widely on voter behaviour and political leadership in Australian scholarly journals, and is a frequent media commentator on Queensland and federal political leadership, election campaigns and voter behaviour. 